\title{
First record of shrews (Eulipotyphla, Soricidae) in the Sierra de Otontepec, an isolated mountain in Veracruz, Mexico
}

\author{
Marco Mayen-Zaragoza ${ }^{1}$, Lázaro Guevara ${ }^{1}{ }^{2 *}$, Giovani Hernández-Canchola ${ }^{1}$ and Livia León-Paniagua ${ }^{1}$ \\ ${ }^{1}$ Museo de Zoología “Alfonso L. Herrera”, Facultad de Ciencias, Universidad Nacional Autónoma de Mexico. Email: mayen.z.marco@ \\ gmail.com (MMZ); lg@st.ib.unam.mx (LG); giovani@ciencias.unam.mx (GHC); llp@ciencias.unam.mx (LLP). \\ ${ }^{2}$ Instituto de Biología, Universidad Nacional Autónoma de Mexico. Correspondence: Av. Universidad 3000, Circuito Exterior S/N \\ Coyoacán, CP. 04510, Ciudad de Mexico Mexico. \\ . Corresponding author
}

\begin{abstract}
Knowledge of the diversity and distribution of mammals in tropical and subtropical regions remains incomplete. This is especially true for many small species inhabiting remote areas with limited access. Here we present the first record of small-eared shrews (Soricidae, Cryptotis) from the Sierra de Otontepec, Mexico, an isolated mountain in the Gulf Coastal Plain that has remained poorly explored (Figure 1). We conducted a short-term survey in the Sierra de Otontepec using pitfall and Sherman traps during August 2016. Taxonomic identification was based on morphological and molecular analyses (Appendix 1). We collected six shrew specimens from the cloud forests in the Sierra de Otontepec (Figure 2). Morphological and molecular characterization indicated that all specimens collected were small-eared shrews belonging to the Cryptotis mexicanus species group (Table 1, Figure 3), a clade which is closely associated with cloud forests. Based on the morphological and molecular evidence, we refer to this population from the Sierra de Otontepec as C. mexicanus, Our results corroborate the importance of continued fieldwork in remote tropical areas. Overall, this finding offers relevant information that could be used to better understand the evolution and biogeographic history of this species group and its habitat.
\end{abstract}

El conocimiento de la diversidad y distribución de los mamíferos en las regiones tropicales y subtropicales sigue siendo incompleto. Esto es particularmente notable para muchas especies pequeñas que habitan en áreas remotas de acceso limitado. Aquí presentamos el primer registro de musarañas (Eulipotyphla, Soricidae) de la Sierra de Otontepec, México, una montaña aislada en la llanura costera del Golfo que ha permanecido escasamente explorada (Figura 1). Nosotros realizamos un estudio a corto plazo en la Sierra de Otontepec utilizando trampas de caida y Sherman durante agosto de 2016. La identificación taxonómica se basó en análisis morfológicos y moleculares (Apéndice 1). Obtuvimos seis especímenes de musarañas en el bosque nuboso de la Sierra de Otontepec (Figura 2). La caracterización morfológica y molecular indicó que todos los especímenes recolectados eran musarañas de orejas pequeñas pertenecientes al grupo de especies de Cryptotis mexicanus (Tabla 1, Figura 3), un clado que está estrechamente asociado con los bosques nubosos. Con base en la evidencia morfológica y molecular, nos referimos a esta población de la Sierra de Otontepec como C. mexicanus. Nuestros resultados corroboran la importancia de continuar trabajo de campo en áreas tropicales remotas. En general, este hallazgo ofrece información relevante que podría usarse para comprender mejor la evolución y la historia biogeográfica de este grupo de especies y su hábitat.

Key words: cloud forests; Cryptotis; Mammalia; small-eared shrews.

C 2019 Asociación Mexicana de Mastozoología, www.mastozoologiamexicana.org

\section{Introduction}

Knowledge of the diversity and geographical distribution of mammals in tropical and subtropical regions remains incomplete (Ceballos and Ehrlich 2009). This is due, in large part, to the fact that many species inhabit remote areas with limited accessibility. This is particularly problematic when collecting small and secretive species that are difficult to find. Small-eared shrews (Eulipotyphla, Soricidae) of the genus Cryptotis Pomel, 1848 comprise a group of small- to medium sized species occurring from southeastern Canada to northern South America (Choate 1970). With about 44 species (Zeballos et al. 2013), Cryptotis is one of the most diverse genera of small mammals in the Americas. Discovery and description of new species, new distributional records, and range extensions for this genus are not unusual even today (Woodman 2010; Guevara et al. 2014; Guevara and Sánchez-Cordero 2018a).

Recently, while working on mammal inventories, our field team discovered a handful of specimens of small- eared shrews in the cloud forest of the Sierra de Otontepec (Figure 1), an isolated mountain in Veracruz, Mexico, where biological inventories and research has been scarce (Hall and Dalquest 1963; Secretaría de Desarrollo Social y Medio Ambiente, SEDESMA, 2007). Here we provide morphological, molecular, and ecological information on these specimens that could be used to better understand the evolutionary and biogeographic history of the genus. Because the fauna in the Sierra de Otontepec is poorly known and most of the natural vegetation in the region has already been altered by human activity, we emphasize the biological relevance of this discovery.

\section{Materials and Methods}

Study area. The Sierra de Otontepec (also known as Sierra de Tantima) lies on the eastern slope of the Sierra Madre Oriental, Veracruz, Mexico (Figure 1). It is a small, isolated volcanic mountain in the Gulf Coastal Plain that reaches an elevation of nearly $1,300 \mathrm{~m}$, and with an extended range of nearly 20 


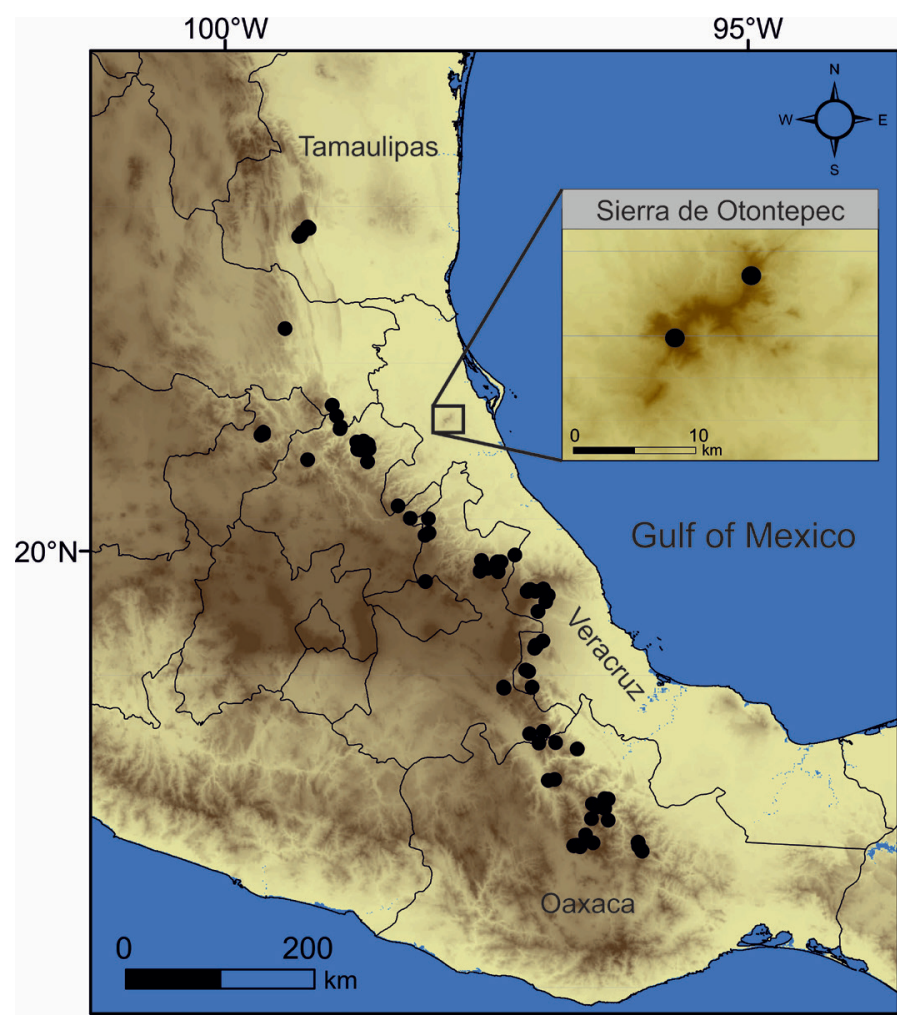

Figure 1. Map showing the known records (black dots) of the small-eared shrew, Cryptotis mexicanus, and the new records from the Sierra de Otontepec.

$\mathrm{km}$ (SEDESMA 2007). The summit vegetation begins at 900 masl and consists largely of cloud forest, making it one of the northernmost stands of cloud forest in the Neotropics.

Fieldwork. The Mexican Ministry of the Environment (SEMARNAT) authorized the capture of mammals under the scientific collector permit SGPA/DGVS/12142/16 issued to LLP. Fieldwork was carried out for 15 consecutive days in August 2016. We used 10 pitfall and 80 Sherman traps, which were placed next to rocks around the bases of the trees and next to fallen trunks. We conducted trapping at two locations covered by dense cloud forest (Site 1: 21.26855278 N, -97.84444 W, 1,080 m; Site 2: 21.24715 N, $-97.895 \mathrm{~W}, 1,020 \mathrm{~m}$ ), which have not been intensively surveyed for small mammals. We followed standard recommendations on specimen capture, sacrifice and preparation (Sikes et al. 2016). We measured ( $\mathrm{mm}$ ) and weighed (g) voucher specimens in the field and deposited skins, skeletons, and tissues samples at the Mammal Collection of the Museo de Zoología "Alfonso L. Herrera", Facultad de Ciencias, Universidad Nacional Autónoma de México (MZFC-M, Mexico City; Appendix 1).

Taxonomic identification. We focused morphological and molecular analyses on the comparison with members of $C$. mexicanus species group (C. magnus, C. nelsoni, C. mexicanus, and $C$. phillipsii) because of their greater similarity in pelage coloration, body size, size of forefeet and claws to the specimens from Sierra de Otontepec. We recorded the following cranial measurements for quantitative comparisons: condylobasal length $(\mathrm{CBL})$, cranial breadth $(\mathrm{CB})$, breadth of the palate across the second molars (M2B), and breadth across the first unicuspids (U1B). All measurements were taken with a Mitutoyo electronic caliper at 0.01 $\mathrm{mm}$ precision under a stereomicroscope (Appendix 1). We performed a principal component analysis (PCA) on the matrix correlation of four cranial variables to describe and evaluate the degree of differentiation among the species of the Cryptotis mexicanus group.

We also conducted a Bayesian Inference to determine the genetic affinity of the specimens from Sierra de Otontepec within the Cryptotis mexicanus group. We amplified the mitochondrial gene cytochrome $b$ (cytb $=1,140 \mathrm{bp}$ ) by a polymerase chain reaction (PCR) using the pair of primers MVZ05 and H15915. The PCR profile included 3 min of initial denaturation at $95^{\circ} \mathrm{C}$, followed by 35 cycles of $30 \mathrm{~s}$ of denaturation at $95^{\circ} \mathrm{C}, 1 \mathrm{~min}$ of annealing at $49^{\circ} \mathrm{C}$, and $2 \mathrm{~min}$ for extension at $72^{\circ} \mathrm{C}$. Finally, we included a step of $5 \mathrm{~min}$ of final extension at $72^{\circ} \mathrm{C}$. We used the Montage PCR purification kit from Millipore, and the ABI PRISM BigDye Terminator cycle sequencing kit with AmpliTaq DNA polymerase for sequencing the $P C R$ products in an $A B I 3730 X L$ sequencer (Applied Biosystems, Seoul, Korea). Both, cleaning of PCR products and sequencing reaction was performed in Macrogen Inc. (Seoul, Korea) following the standard protocols. The sequences generated were deposited in the GenBank database (Accession \#'s MK286564-MK286565). We included $21 \mathrm{cytb}$ sequences from the $C$. mexicanus species group and one sequence of $C$. parvus (used as outgroup) housed in the GenBank database (see accession numbers

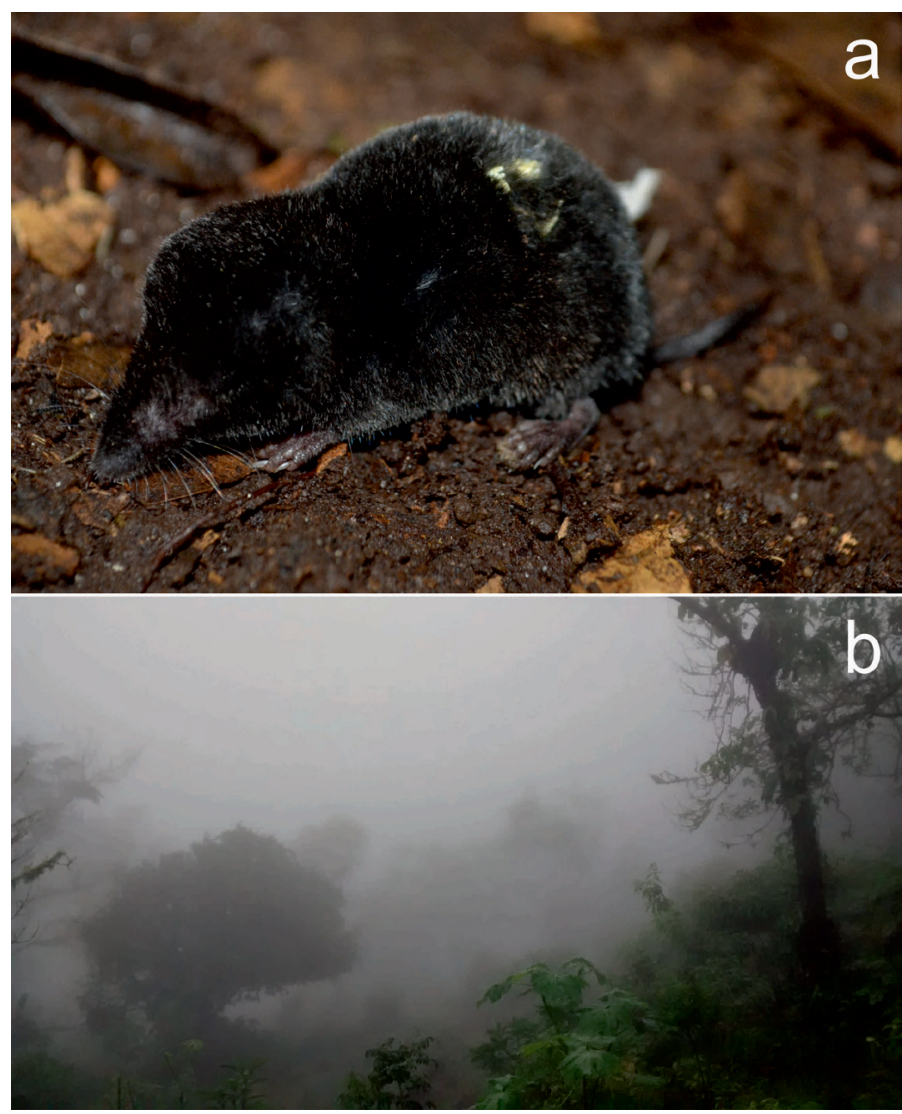

Figure 2. A) Specimen of a small-eared shrew collected in Sierra de Otontepec Mexico. B) Typical cloud forest habitat of the Sierra de Otontepec, where small-eared shrews were collected. 
on Figure 4, downloaded on 07 November, 2018). Using PartitionFinder 2 (Lanfear et al. 2017), we selected the best scheme of partition and evolution model $\left(c y t b_{[1]}=\mathrm{SYM}+\Gamma\right.$; $\left.c y t b_{[2]}=\mathrm{F} 81+\mathrm{l} ; c y t b_{[3]}=\mathrm{GTR}+\mathrm{I}\right)$. We then incorporated this partition and evolution model in a phylogenetic analysis using Bayesian inference (MrBayes 3.2.3; Ronquist et al. 2012). We used three hot and one cold chains in two independent runs of 10 million generations, sampling data every 1,000 iterations. The final topology was obtained using a majority tree consensus and considering a burn-in of $25 \%$. We checked the convergence of our results and a good sampling (ESS > 200) in Tracer 1.6.

\section{Results}

We obtained a total of six shrew specimens in the cloud forests from the Sierra de Otontepec; four were collected with pitfall traps and two with Sherman traps. The sample included three adult males (MZFC-M 16221, 16223-16224) and three adult females (MZFC-M 16219-16220, 16222), one of which was pregnant with five embryos (MZFC-M 16222). Other genera of mammals collected in this short-term survey were Handleyomys (rice rat), Sigmodon (cotton rat), and Marmosa (mouse opossum). The shrew specimens displayed previously reported external diagnostic characters of the Cryptotis mexicanus species group (Choate 1970; Guevara and Sánchez-Cordero 2018b). Principal components 1 and 2 explained $95 \%$ of the variation in the data (PC $1=90$ $\%$ and $P C 2=5 \%)$. The breadth of the palate across the second molars (M2B) and condylobasal length (CBL) contributed strongly to the first factor axis, providing a measure of overall cranial size. A plot of the two PCs showed that the specimens from Sierra de Otontepec tended to plot among the smaller species within the C. mexicanus species group (C. phillipsii and C. mexicanus) and overlapped partly with previously known specimens of $C$. mexicanus (Table 1 ; Figure 3). Bayesian Inference indicated that specimens from the Sierra de Otontepec are nested within C. mexicanus, which is supported by a high posterior probability (Figure 4). The rest of the relationships within the $C$. mexicanus species group resemble previous phylogenetic hypothesis (Guevara and Cervantes 2014; He et al. 2015).

\section{Discussion and conclusions}

Morphological characterization indicates that the specimens collected in Sierra de Otontepec belong to the Cryptotis mexicanus species group, a clade comprising four species highly associated with cloud forests (C. magnus, $C$.

Table 1. Loadings of four cranial measurements on the first two axes (PCs 1 and 2) of a principal component analysis of small-eared shrews (Cryptotis) from Mexican cloud forests.

\begin{tabular}{lll}
\hline & PC 1 & PC 2 \\
\hline CBL & -0.955133 & 0.180397 \\
CB & -0.941390 & 0.231200 \\
M2B & -0.964130 & -0.088268 \\
U1B & -0.933362 & -0.326616 \\
\hline
\end{tabular}

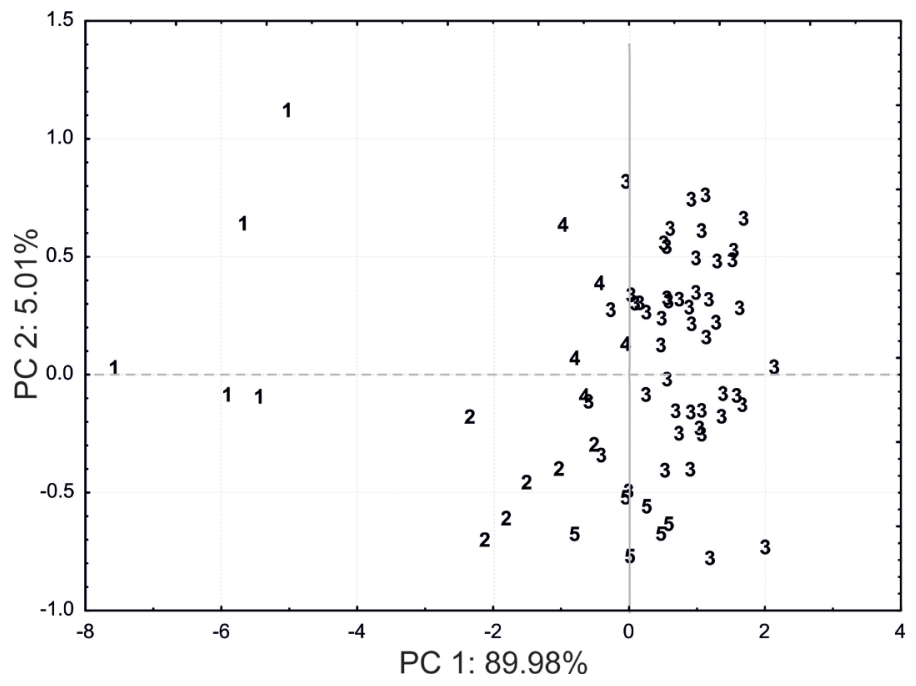

Figure 3. Plot of the first 2 principal components from a principal component analysis (PCA) of four cranial measurements from C. magnus (1), C. nelsoni (2), C. mexicanus (3), C. phillipsii (4), and the specimens from Sierra de Otontepec (5).

mexicanus, C. nelsoni, and C. phillipsii; González-Ruiz et al. 2014; Guevara and Sánchez-Cordero 2018b). The fact that specimens from Sierra de Otontepec are morphological similar and are phylogenetically nested within C. mexicanus implies that there is no justification for the recognition of a new species for this new population. Therefore, we refer to the population from the Sierra de Otontepec as C. mexicanus, Interestingly, this first record of small-eared shrews in the Sierra de Otontepec is consistent with the potential distribution of the $C$. mexicanus group based on models of its climatic requirements using correlative techniques (Guevara and Sánchez-Cordero 2018b).

Our discovery corroborates the importance of continued surveys in remote tropical areas (Guevara et al. 2014). Very little is known about the biota and biogeographic history of the Sierra de Otontepec (SEDESMA 2007), which has gone largely unnoticed in the study of cloud forest vegetation. Hence, this discovery of small-eared shrews could also be used to better understand the origin and history

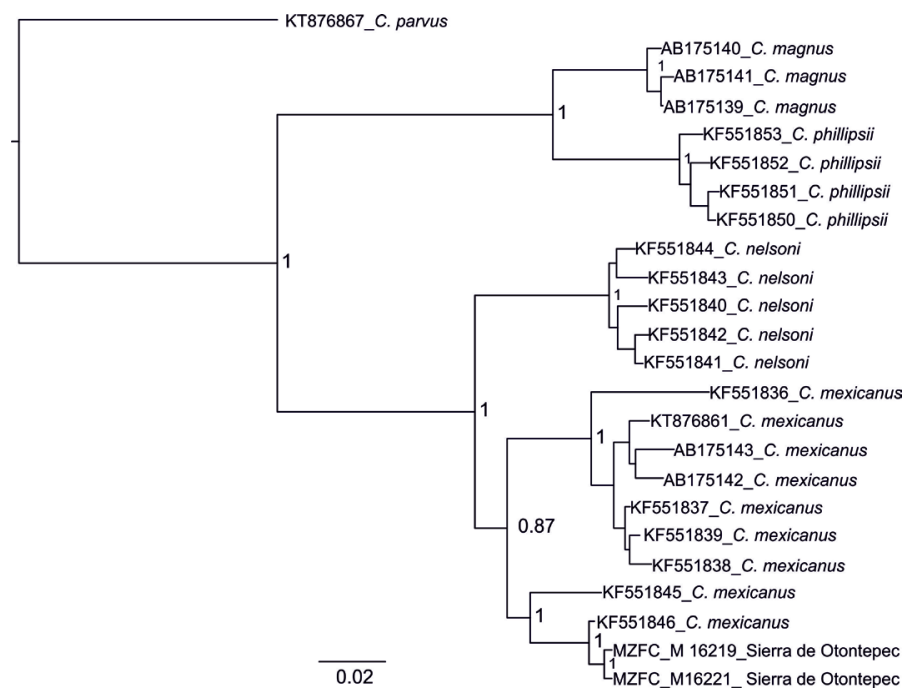

Figure 4. Majority-rule consensus tree from a Bayesian Inference showing the position of the specimens from Otontepec within the Cryptotis mexicanus species group. The numbers on clades indicate the posterior probability for each clade. The accession numbers of GenBank precede the scientific names. 
of one of the northernmost islands of cloud forest in the Neotropical region. Finally, we highlight the relevance of montane cloud forest fragments like the Sierra de Otontepec because they are important reservoirs of endemic and endangered species that have a critical role in maintaining landscape-level biodiversity in an ecosystem with rapid rates of clearing and global conservation priority (Wilson and Rhemtulla 2018).

\section{Acknowledgments}

Financial support for fieldwork was provided by Fundación Pedro y Elena Hernández A. C. We thank A. Garrido, U. O. García-Vázquez, M. Trujano, J. C. Sánchez García and A. Jhosefat for all the logistic support in the field. We also thank Y. A. Gómez-Jiménez for his assistance in depositing the specimens in the MZFC-M. We thank the following curators and collection managers for access to the facilities and specimens included in Appendix 1: F. A. Cervantes and Y. Hortelano (CNMA); R. M. Timm (KU), J. Ramirez-Pulido and N. GonzálezRuíz (UAMI); and S. Peurach and N. Woodman (USNM).

\section{Literature cited}

Ceballos, G., and P. R. Ehrlich. 2009. Discoveries of new mammal species and their implications for conservation and ecosystem services. Proceedings of the National Academy of Sciences 106:3841-3846. doi.org/10.1073/pnas.0812419106

CHOATE, J. R. 1970. Systematics and zoogeography of Middle American shrews of the genus Cryptotis. University of Kansas. Museum of Natural History 19:195-317.

Gonzalez-Ruiz, N., J. Ramírez-Pulido, and M. Gual-Díaz. 2014. Mamíferos del bosque mesófilo de montaña en México. Pp. 305-326 in Bosques mesófilos de montaña de México: diversidad, ecología y manejo (Gual-Díaz, M., and A. RendónCorrea, eds.). Comisión Nacional para el Conocimiento y Uso de la Biodiversidad, Mexico City, Mexico.

Guevara, L., and F. A. Cervantes. 2014. Molecular systematics of small-eared shrews (Soricomorpha, Mammalia) within Cryptotis mexicanus species group from Mesoamérica. Acta theriologica 59:233-242.

Guevara, L., V. Sánchez-Cordero, V., L. León-Paniagua, and N. Woodman. 2014. A new species of small-eared shrew (Mammalia, Eulipotyphla, Cryptotis) from the Lacandona rain forest, Mexico. Journal of Mammalogy 95:739-753.

Guevara, L., And V. Sánchez-Cordero. 2018a. New records of a critically endangered shrew from Mexican cloud forests (Soricidae, Cryptotis nelsoni) and prospects for future field research. Biodiversity Data Journal 6:p.e26667.

Guevara, L., and V. Sánchez-Cordero. 2018b. Patterns of morphological and ecological similarities of small-eared shrews (Soricidae, Cryptotis) in tropical montane cloud forests from Mesoamerica. Systematics and Biodiversity. doi.org/10. 1080/14772000.2017.1470582

HaLL, E.R. AND W.W. DalQuest. 1963. The mammals of Veracruz. University of Kansas Publications, Museum of Natural History 14:165-362.

He, K., N. Woodman, S. Boaglio, M. Roberts, S. Supekar, and J.E. MALDONADO. 2015. Molecular phylogeny supports repeated adaptation to burrowing within small-eared shrews genus of Cryptotis (Eulipotyphla, Soricidae). PloS one 10: p.e0140280.

Lanfear, R., P. B. Frandsen, A. M., Wright, T. Senfeld, and B. CALCOTT. 2017. PartitionFinder 2: new methods for selecting partitioned models of evolution for molecular and morphological phylogenetic analyses. Molecular Biology Evolution 34:772-773.

Ronquist, F., M., Teslenko, P. Van der Mark, D. L. Ayres, A. Darling, S. Hônna, B. LaRget, L. Liu, M. A. Suchard, and J. P. Hulsenbeck. 2012. Mrbayes 3.2: efficient bayesian phylogenetic inference and model choice across a large model space. Systematic Biology 61:539-542.

Secretaria de Desarrollo Social y Medio Ambiente, Sedesma. 2007. Programa de Manejo de la Reserva Ecolgica Sierra de Otontepec. Serie: "Protegamos Nuestro Medio Ambiente". Registro Estatal de Espacios Naturales Protegidos. Gobierno del Estado de Veracruz.

Sikes, R.S. and Animal Care and Use Committee of the American Society OF Mammalogists. 2016. Guidelines of the American Society of Mammalogists for the use of wild mammals in research and education. Journal of Mammalogy 97:663-688.

WILSON, S. J., AND J. .M. RHEMTULLA. 2018. Small montane cloud forest fragments are important for conserving tree diversity in the Ecuadorian Andes. Biotropica 50:586-597.

Woodman, N. 2010. Two new species of shrews (Soricidae) from the western highlands of Guatemala. Journal of Mammalogy 91:566-579.

Zeballos, H., K. Pino, C. E. Medina, Pari, A., D. Chavez, N. Tinoco, and G. Ceballos. 2018. A new species of small-eared shrew of the genus Cryptotis (Mammalia, Eulipotyphla, Soricidae) from the northernmost Peruvian Andes. Zootaxa 4377:51-73.

Associated editor: Jesús Maldonado

Submitted: September 28, 2018; Reviewed: October 24, 2018;

Accepted: January 15, 2018; Published on line: January 16, 2019. 
Appendix 1.

Specimens examined and measurements (CBL-U1B) used for the morphological comparison (see methods for details). Specimens examined are housed in the following collections (followed by their abbreviations): National Collection of Mammals, Mexico City (CNMA); The University of Kansas Natural History Museum, Lawrence, Kansas (KU); Museum of Zoology 'Alfonso L. Herrera', Mexico City (MZFC); Collection of Mammals, Universidad Autónoma Metropolitana, Iztapalapa, Mexico City (UAMI); and National Museum of Natural History, Washington, District of Columbia (USNM).

\begin{tabular}{|c|c|c|c|c|c|c|}
\hline SPECIES & MUSEUM & $\begin{array}{l}\text { CATALOGUE } \\
\text { NUMBER }\end{array}$ & CBL & $\mathrm{CB}$ & M2B & U1B \\
\hline Cryptotis mexicanus & MZFC & 637 & 18.5 & 9.7 & 5.2 & 2.5 \\
\hline Cryptotis mexicanus & MZFC & 638 & 18.9 & 9.6 & 5.2 & 2.5 \\
\hline Cryptotis mexicanus & MZFC & 639 & 19.1 & 10.2 & 5.3 & 2.5 \\
\hline Cryptotis mexicanus & MZFC & 640 & 18.5 & 9.4 & 5.3 & 2.5 \\
\hline Cryptotis mexicanus & $\mathrm{KU}$ & 29548 & 18.4 & 10.0 & 5.6 & 2.6 \\
\hline Cryptotis mexicanus & $\mathrm{KU}$ & 29561 & 18.4 & 10.0 & 5.3 & 2.5 \\
\hline Cryptotis mexicanus & $\mathrm{KU}$ & 29552 & 18.5 & 9.8 & 5.3 & 2.5 \\
\hline Cryptotis mexicanus & $\mathrm{KU}$ & 29528 & 18.6 & 10.3 & 5.2 & 2.5 \\
\hline Cryptotis mexicanus & $\mathrm{KU}$ & 29555 & 18.7 & 9.9 & 5.2 & 2.5 \\
\hline Cryptotis mexicanus & $\mathrm{KU}$ & 29554 & 18.7 & 10.0 & 5.3 & 2.5 \\
\hline Cryptotis mexicanus & CNMA & 42741 & 17.6 & 9.4 & 5.1 & 2.4 \\
\hline Cryptotis mexicanus & CNMA & 42733 & 18.1 & 9.8 & 5.1 & 2.4 \\
\hline Cryptotis mexicanus & CNMA & 42748 & 18.3 & 9.5 & 5.2 & 2.4 \\
\hline Cryptotis mexicanus & CNMA & 42756 & 18.8 & 9.8 & 5.1 & 2.4 \\
\hline Cryptotis mexicanus & CNMA & 42744 & 18.9 & 10.0 & 5.3 & 2.4 \\
\hline Cryptotis mexicanus & MZFC & 8354 & 18.3 & 10.0 & 5.2 & 2.6 \\
\hline Cryptotis mexicanus & MZFC & 8332 & 18.3 & 9.9 & 5.0 & 2.3 \\
\hline Cryptotis mexicanus & MZFC & 8386 & 18.4 & 10.2 & 5.3 & 2.5 \\
\hline Cryptotis mexicanus & MZFC & 8400 & 18.5 & 9.8 & 5.0 & 2.3 \\
\hline Cryptotis mexicanus & USNM & 69733 & 18.4 & 9.7 & 5.4 & 2.4 \\
\hline Cryptotis mexicanus & USNM & 69615 & 18.4 & 9.7 & 5.3 & 2.4 \\
\hline Cryptotis mexicanus & USNM & 69609 & 18.4 & 9.8 & 5.3 & 2.5 \\
\hline Cryptotis mexicanus & USNM & 69605 & 18.6 & 9.9 & 5.4 & 2.4 \\
\hline Cryptotis mexicanus & CNMA & 29429 & 18.9 & 9.8 & 5.3 & 2.4 \\
\hline Cryptotis mexicanus & CNMA & 29431 & 19.0 & 10.0 & 5.3 & 2.4 \\
\hline Cryptotis mexicanus & CNMA & 29427 & 19.3 & 10.4 & 5.2 & 2.5 \\
\hline Cryptotis mexicanus & USNM & 68299 & 18.5 & 9.5 & 5.2 & 2.3 \\
\hline Cryptotis mexicanus & USNM & 68311 & 18.7 & 9.9 & 5.2 & 2.4 \\
\hline Cryptotis mexicanus & USNM & 68303 & 18.7 & 9.6 & 5.3 & 2.3 \\
\hline Cryptotis mexicanus & USNM & 68305 & 18.8 & 9.7 & 5.0 & 2.3 \\
\hline Cryptotis mexicanus & CNMA & 29989 & 17.5 & 9.7 & 5.0 & 2.3 \\
\hline Cryptotis mexicanus & CNMA & 35261 & 18.6 & 10.0 & 5.1 & 2.3 \\
\hline Cryptotis mexicanus & CNMA & 35260 & 18.7 & 10.2 & 5.1 & 2.5 \\
\hline Cryptotis mexicanus & CNMA & 34859 & 18.8 & 10.0 & 5.2 & 2.4 \\
\hline Cryptotis mexicanus & CNMA & 29991 & 19.0 & 10.1 & 5.2 & 2.5 \\
\hline Cryptotis mexicanus & CNMA & 29986 & 19.0 & 10.3 & 5.6 & 2.6 \\
\hline Cryptotis mexicanus & CNMA & 43060 & 18.4 & 9.7 & 5.1 & 2.3 \\
\hline Cryptotis mexicanus & CNMA & 43059 & 18.4 & 9.6 & 5.2 & 2.4 \\
\hline Cryptotis mexicanus & CNMA & 43053 & 19.1 & 9.9 & 5.3 & 2.5 \\
\hline
\end{tabular}

\begin{tabular}{|c|c|c|c|c|c|c|}
\hline Cryptotis mexicanus & USNM & 68525 & 18.4 & 10.0 & 5.2 & 2.4 \\
\hline Cryptotis mexicanus & USNM & 68523 & 18.4 & 9.8 & 5.3 & 2.3 \\
\hline Cryptotis mexicanus & USNM & 68526 & 18.4 & 10.2 & 5.1 & 2.4 \\
\hline Cryptotis mexicanus & USNM & 68532 & 18.5 & 10.0 & 5.2 & 2.4 \\
\hline Cryptotis mexicanus & USNM & 68528 & 18.7 & 9.9 & 5.3 & 2.3 \\
\hline Cryptotis mexicanus & UAMI & 11169 & 19.2 & 10.1 & 5.4 & 2.7 \\
\hline Cryptotis mexicanus & UAMI & 11170 & 19.2 & 10.2 & 5.2 & 2.5 \\
\hline Cryptotis mexicanus & UAMI & 11172 & 18.8 & 9.8 & 5.1 & 2.4 \\
\hline Cryptotis mexicanus & UAMI & 11176 & 19.0 & 10.1 & 5.2 & 2.4 \\
\hline Cryptotis mexicanus & UAMI & 11177 & 19.6 & 10.1 & 5.4 & 2.5 \\
\hline Otontepec & MZFC & 16224 & 18.6 & 9.7 & 5.3 & 2.6 \\
\hline Otontepec & MZFC & 16223 & 18.9 & 10.0 & 5.4 & 2.7 \\
\hline Otontepec & MZFC & 16222 & 19.5 & 10.1 & 5.4 & 2.8 \\
\hline Otontepec & MZFC & 16221 & 18.6 & 9.9 & 5.4 & 2.7 \\
\hline Otontepec & MZFC & 16220 & 18.8 & 9.8 & 5.3 & 2.6 \\
\hline Otontepec & MZFC & 16219 & 18.8 & 9.7 & 5.3 & 2.6 \\
\hline Cryptotis nelsoni & CNMA & 41961 & 19.0 & 10.1 & 5.6 & 2.6 \\
\hline Cryptotis nelsoni & CNMA & 41993 & 19.1 & 10.4 & 5.5 & 2.8 \\
\hline Cryptotis nelsoni & CNMA & 41959 & 19.4 & 10.6 & 5.8 & 2.9 \\
\hline Cryptotis nelsoni & CNMA & 41956 & 19.5 & 10.3 & 5.8 & 2.8 \\
\hline Cryptotis nelsoni & CNMA & 41992 & 19.9 & 10.3 & 5.7 & 2.8 \\
\hline Cryptotis nelsoni & CNMA & 41960 & 19.9 & 10.6 & 5.9 & 2.8 \\
\hline Cryptotis magnus & CNMA & 29468 & 23.0 & 11.3 & 6.3 & 3.1 \\
\hline Cryptotis magnus & CNMA & 29469 & 22.7 & 11.3 & 6.3 & 2.9 \\
\hline Cryptotis magnus & CNMA & 33609 & 23.3 & 11.7 & 6.9 & 3.3 \\
\hline Cryptotis magnus & CNMA & 29823 & 22.4 & 11.3 & 6.5 & 3.2 \\
\hline Cryptotis magnus & CNMA & 43057 & 22.2 & 11.3 & 6.3 & 3.2 \\
\hline Cryptotis phillipsii & CNMA & 44725 & 19.4 & 10.0 & 5.4 & 2.5 \\
\hline Cryptotis phillipsii & CNMA & 44727 & 20.0 & 9.9 & 5.8 & 2.5 \\
\hline Cryptotis phillipsii & CNMA & 44728 & 20.2 & 10.3 & 5.5 & 2.5 \\
\hline Cryptotis phillipsii & CNMA & 44729 & 19.9 & 10.0 & 5.5 & 2.5 \\
\hline Cryptotis phillipsii & CNMA & 44730 & 19.7 & 10.0 & 5.6 & 2.6 \\
\hline
\end{tabular}


64 THERYA Vol. 10 (1):59-63 